\title{
A proposal of a description of the operating conditions of diesel-electric locomotives
}

\begin{abstract}
The paper presents a proposal of a description of the operating conditions of diesel-electric locomotives. The proposal is a result of the operational experience and the analysis of the locomotive operation. It constitutes a significant simplification in relation to the descriptions currently used by domestic carriers. The paper also presents examples of analyses of the operating conditions of locomotives using the proposed method.
\end{abstract}

Key words: diesel locomotives, operating conditions of locomotives, fuel consumption

\section{Propozycja opisu warunków eksploatacji lokomotyw spalinowych z przekładniami elektrycznymi}

\begin{abstract}
W pracy przedstawiono propozycję opisu warunków eksploatacji lokomotyw spalinowych z przekladniami elektrycznymi. Propozycja ta jest wynikiem doświadczeń eksploatacyjnych przy analizie pracy lokomotyw i jest łatwiejsza w użyciu niż opisy wykorzystywane aktualnie przez krajowych przewoźników. Przedstawiono również przykłady analizy warunków eksploatacji lokomotyw spalinowych wedlug zaproponowanej metody ich opisu.

Słowa kluczowe: lokomotywy z silnikami spalinowymi, warunki eksploatacji lokomotyw, zużycie paliwa
\end{abstract}

\section{Introduction}

The basis of the process of minimizing fuel consumption and exhaust emissions of traction vehicles powered by internal combustion engines, such as diesel locomotives is in-depth knowledge of the operating conditions of these vehicles $[1,7,11,12,14,15,17]$. The knowledge of the structure of the operating conditions based on appropriate models may allow predicting and standardizing the fuel consumption and a proper selection of locomotives for given applications $[6,7,8]$. This knowledge should be taken into account when designing new traction vehicles as well as modifying the design of the traction vehicles that are already in-service $[9,10,13,15]$. The paper presents a proposal of a description of the operating conditions of diesel-electric locomotives that can be used to predict their fuel consumption, standardize and assess their energy efficiency.

\section{Propulsion system of a diesel-electric locomotive}

The largest group of locomotives operated in Poland are diesel-electric locomotives. The schematics of the energy flow of this type of locomotive are shown in Figure 1. The heat energy released by combustion of fuel is converted into mechanical work in the form of a rotational motion of the engine crankshaft. The main takeoff of the mechanical energy is the main generator that converts this work into electrical energy. Then, in the traction motors, the electrical energy is converted again into a mechanical work transmitted through a gear to the wheel sets. The mechanical energy produced in a combustion engine is also used to drive auxiliary devices such as the air compressor, engine cooling fan, etc.

\section{Wstęp}

W procesie minimalizacji zużycia paliwa i emisji związków toksycznych pojazdów trakcyjnych napędzanych silnikami spalinowymi, jakimi są lokomotywy spalinowe, podstawą jest dokładna znajomość warunków eksploatacji tych pojazdów [1, 7, 11, 12, 14, 15, 17]. Znajomość ta, przy zastosowaniu odpowiednich modeli, może umożliwiać prognozowanie i normowanie zużycia paliwa oraz dokonanie odpowiedniego doboru lokomotywy do określonego zadania $[6,7,8]$. Znajomość ta powinna być brana pod uwagę zarówno przy projektowaniu nowych pojazdów trakcyjnych, jak i podczas dokonywania zmian w konstrukcji już eksploatowanych $[9,10,13,15]$. W pracy przedstawiono propozycję opisu struktury warunków eksploatacji lokomotyw spalinowych z przekładniami elektrycznymi, która może być wykorzystana do prognozowania i normowania zużycia paliwa oraz oceny ich efektywności energetycznej.

\section{Układ napędowy lokomotywy spalinowej z przekladnią elektryczną}

Najliczniejszą grupę lokomotyw spalinowych eksploatowanych w Polsce stanowią lokomotywy z przekładnią elektryczną. Schemat przepływu energii w tego typu lokomotywach przedstawiono na rys. 1. Energia cieplna uwolniona w procesie spalania paliwa w cylindrze silnika spalinowego jest zamieniana na energię mechaniczną. Głównym odbiornikiem energii mechanicznej jest prądnica główna, w której następuje konwersja tej pracy na energię elektryczną. Następnie w silnikach trakcyjnych energia elektryczna jest zamieniana ponownie na pracę mechaniczną, przekazywaną za pomocą przekładni zębatej do zestawów kołowych. Energia mechaniczna wytworzona w silniku spalinowym wykorzystywana jest również do napędu urządzeń pomocniczych, takich jak sprężarka powietrza, wentylatory układu chłodzenia silnika spalinowego itd. 


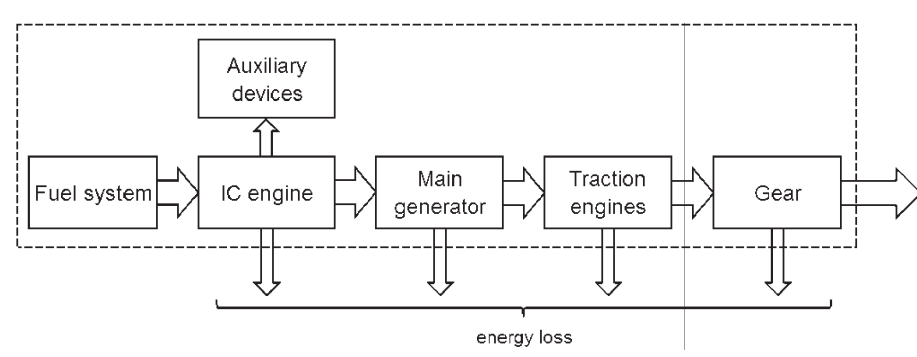

Fig. 1. Schematics of the locomotive propulsion system fitted with a combustion engine [7]

Rys. 1. Schemat uktadu napędowego lokomotywy spalinowej [7]

\section{Description of the operating conditions of railway traction vehicles}

During operation of traction vehicles, to which diesel locomotives belong, there is a need to solve a number of operational and economy related issues such as maintenance planning and calculation of the costs of operation. Figure 2 [16] shows the structure of a railway traction vehicle operating conditions used by PKP CARGO SA to achieve the above-listed objectives.

Figure 2 clearly shows that the presented structure is very complex. This is because it is used for the analysis of not only the mere locomotives, but also the work of the train driving crew that includes drivers and their assistants. This structure includes all possible types of a traction vehicle operation including such that are not used today. This applies to substitute operation such as the heating of buildings and compressed air supply to facilities. In addition, even in the case of an analysis of a railway traction vehicle the use of this division may cause some difficulties. This is because shunting operation was included in the traction and non-traction operation, but from the point of view of a diesel engine load there is no difference between the two operating modes.

A much simpler structure of railway traction vehicle operating conditions is shown in Figure 3. This structure [7] contains the division of the locomotive operation into shunting and transport operations and does not include its ride without the rolling stock. The proposed classification of locomotive loads in [7] allows the best choice to be made of engines for the analysed type of operation (shunting or transport) in terms of minimization of the fuel consumption. In this method, the selected mode of the locomotive operation is described quantitatively by a probability density function of the locomotive load treated as a random variable.

The examples of the structures of the operating conditions of traction vehicles shown above are limited only to the locomotive operation, while the stops for repairs and periodic inspections as well as the stops of the locomotive as a reserve unit where omitted.

\section{Opis warunków eksploatacji pojazdów trakcyjnych}

Podczas użytkowania pojazdów trakcyjnych, do których zalicza się lokomotywy spalinowe, pojawia się konieczność rozwiązywania wielu problemów eksploatacyjnych i ekonomicznych, np. planowania przeglądów i obliczania kosztów eksploatacji. Na rysunku 2 [16] przedstawiono strukturę warunków pracy pojazdu trakcyjnego wykorzystywaną przez PKP CARGO S.A. do realizacji wymienionych wyżej celów.

Jak wynika $\mathrm{z}$ analizy rysunku, przedstawiona struktura jest bardzo rozbudowana. Wynika to z jej wykorzystywania nie tylko do analizy pracy samych lokomotyw, ale także do analizy pracy drużyn trakcyjnych, do których zaliczają się maszyniści i pomocnicy maszynistów. Ta struktura uwzględnia wszystkie możliwe rodzaje pracy pojazdu, nawet obecnie niewykorzystywane. Dotyczy to pracy zastępczej, w skład której wchodzi ogrzewanie obiektów oraz zasilanie obiektów sprężonym powietrzem. Ponadto w sytuacji analizy wyłącznie pojazdu trakcyjnego stosowanie powyższego podziału może sprawiać pewne problemy, wynikające z uwzględnienia pracy manewrowej zarówno w pracy pociągowej, jak i pozapociągowej, chociaż z punktu widzenia np. obciążenia silnika spalinowego oba przypadki pracy manewrowej niczym się od siebie nie różnią.

Znacznie prostszą strukturę pracy przedstawiono na rys. 3. Ta struktura [7] zawiera podział pracy lokomotywy na manewrową oraz liniową i nie zawiera np. pracy przesyłowej, polegającej na jeździe bez wagonów. Zaproponowana w pracy [7] klasyfikacja obciążeń lokomotyw spalinowych umożliwia przeprowadzanie doboru najlepszej lokomotywy dla analizowanego charakteru pracy (manewrowa lub liniowa), ze względu na minimalizację zużycia paliwa. $\mathrm{W}$ tej metodzie praca lokomotywy opisywana jest funkcją gęstości prawdopodobieństwa obciążenia lokomotywy traktowanego jako zmienna losowa.

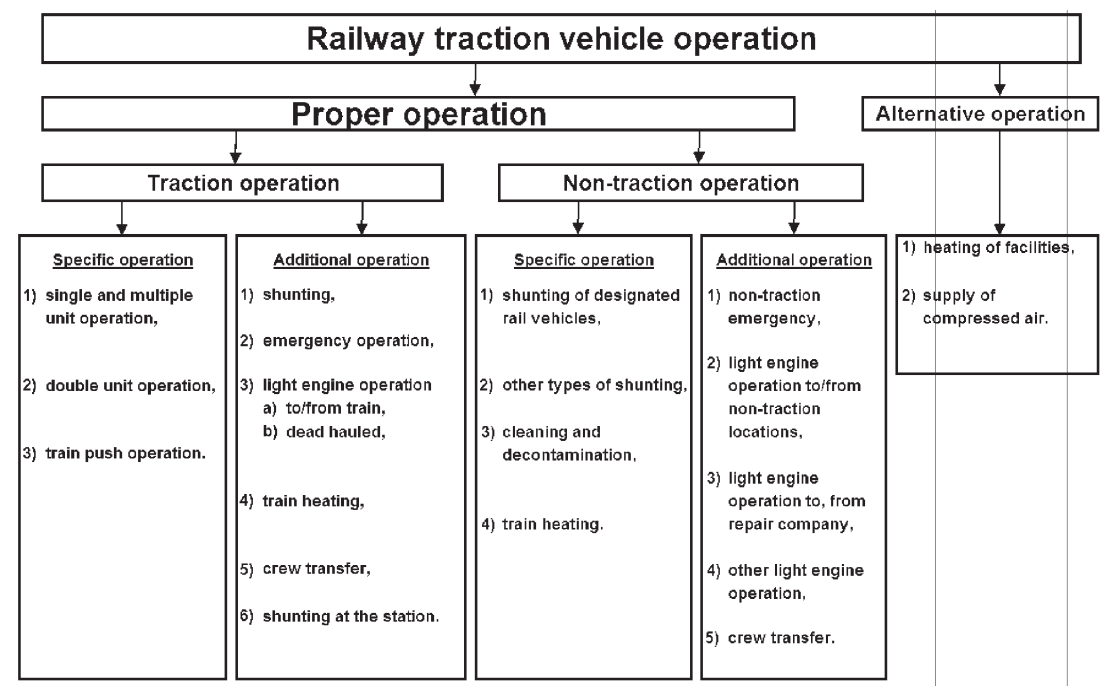

Fig. 2. A structure of the operating conditions of a railway traction vehicle [16] Rys. 2. Struktura warunków eksploatacji pojazdu trakcyjnego wg [16] 
Figure 4 shows a time structure of service conditions during operation of a cargo ship [3], which is an autonomous energy system, similar to land transport vehicles: cars, trucks, buses, light and heavy-duty vehicles and diesel locomotives [2].

The task of engines in all of these groups of vehicles is to generate motion (running, seagoing), carry loads and in some cases perform other tasks (cargo cooling, ore mining, fishing, and the like.) [2].

An advantage of this structure is that it includes almost all the operating conditions of a ship. After introduction of appropriate coefficients there is a possibility to perform an accurate energy analysis of a ship.

\section{A structure of the operating states of a diesel- electric locomotive}

The purpose of the energy system is to provide mechanical energy, electricity and heat to separate receivers or groups of receivers. In general, the system includes elements that consume fuel: combustion engines, boilers (heat source), energy-converting equipment (generators, turbines) as well as devices for changing of the energy parameters (gears,

a)

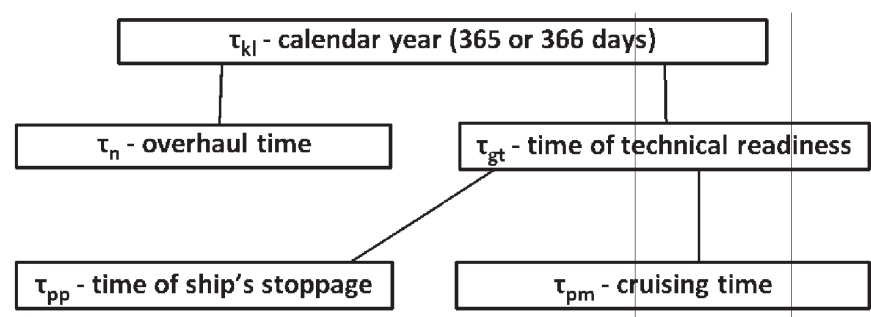

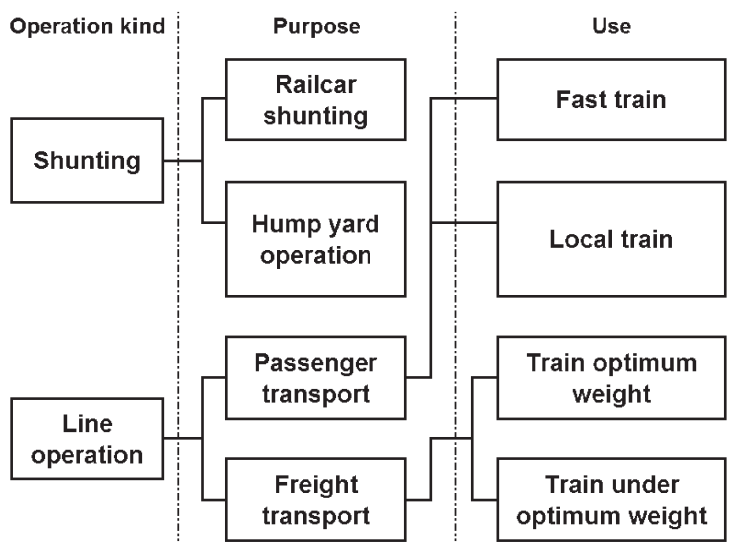

Fig. 3. Classification of loads of the diesel-electric locomotives [7]

Rys. 3. Klasyfikacja obciążen lokomotyw spalinowych wg [7]

Przedstawione wyżej przykłady struktur warunków eksploatacji pojazdów trakcyjnych ograniczają się jedynie do pracy lokomotywy, pominięte natomiast zostały warunki eksploatacji obejmujące postoje podczas napraw i przeglądów okresowych, a także postoje w rezerwie.

b)

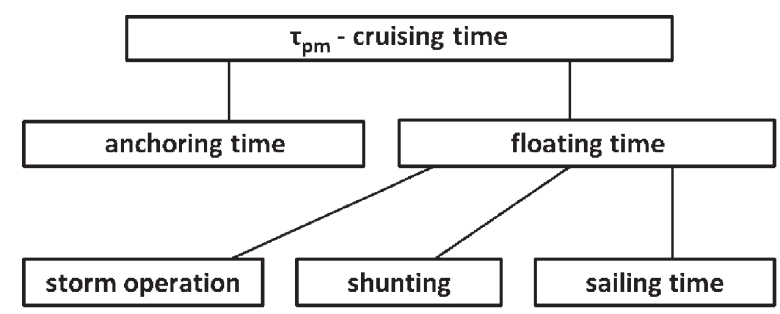

Fig. 4. A general structure of the operating conditions of ships: a) operating conditions of a ship in 1 year, b) operating conditions of a ship at sea [3] Rys. 4. Ogólna struktura warunków eksploatacji statków: a) warunki eksploatacji statków w okresie 1 roku, b) warunki eksploatacji statków podczas pobytu w morzu [3]

boilers). Stand-alone power systems for road and rail and vessels in maritime transport have many analogies in this respect [2]. For further analysis a time structue of the operating conditions of combustion engines modeled on the solution shown in Figure 4 has been proposed. The proposed general time structure of the operating states of the diesel-electric locomotives (Fig. 5) is based on the operational experience of one of the authors and uses rail transport terminology.

A major problem in the analysis of the operating states of locomotives are cyclical changes of the external conditions. These conditions can have a direct impact on the locomotive operation, resulting, for example, from a different friction coefficient between the wheels and the rails in autumn or the need to preheat the engines. Noticeable is also the indirect effect of the external conditions on the operation of locomotives such as an increase in the weight of the fuel carried in wintertime. In order to take into account the impact of these factors on the operation of diesel locomotives an analysis of the time structure of their operating states for a period of one year should be performed. During this period, the locomotive
$\mathrm{Na}$ rysunku 4 przedstawiono strukturę warunków eksploatacji dla statku towarowego [3], który, podobnie jak samochody osobowe i ciężarowe, autobusy, maszyny robocze i lokomotywy spalinowe napędzane tłokowymi silnikami spalinowymi, stanowi autonomiczny energetycznie środek transportu [2]. Zadaniem silników napędowych we wszystkich tych grupach pojazdów jest zapewnienie możliwości ruchu (jazdy, pływania) i przewożenia określonych ładunków, niekiedy również realizacji innych procesów technologicznych (chłodzenie ładunku, wydobywanie urobku, połowy i in.) [2].

Zaletą powyższej struktury jest to, że obejmuje ona prawie wszystkie warunki eksploatacji jednostki pływającej. Umożliwia to, po wprowadzeniu odpowiednich współczynników udziału, dokładną analizę energetyczną statków.

\section{Struktura warunków eksploatacji lokomotywy spalinowej}

Zadaniem układu energetycznego jest dostarczenie energii mechanicznej, elektrycznej i cieplnej do odpowiednich wydzielonych odbiorników oraz grup odbiorników. Ogólnie 


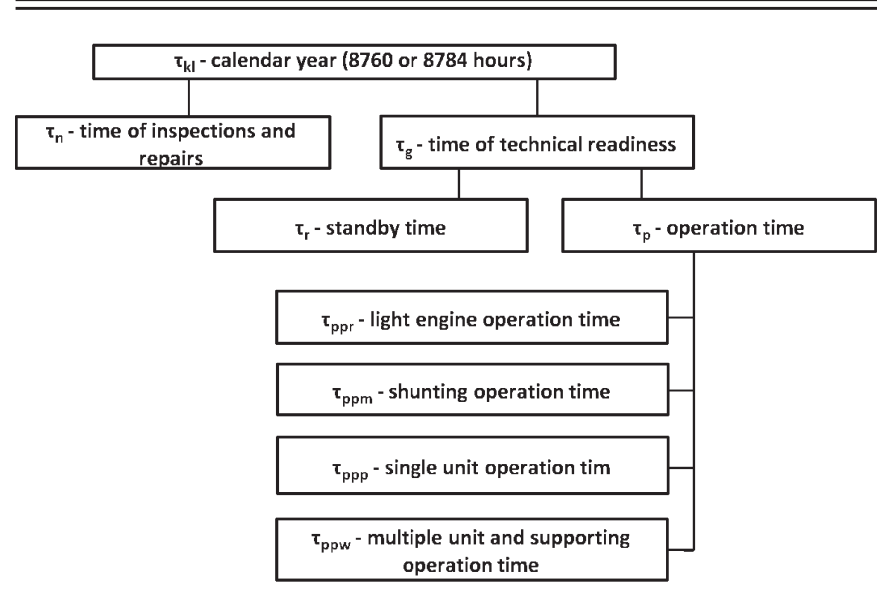

Fig. 5. A general time structure of the operating states of the diesel-electric locomotives

Rys. 5. Ogólna struktura czasowa warunków eksploatacji lokomotyw spalinowych z przektadniami elektrycznymi

is under scheduled inspections and repairs in time $\tau \mathrm{n}$ and in a state of technical readiness in time $\tau$ g. According to the proposed time structure, which is presented in Figure 5, the following states of operation of diesel-electric locomotives can be listed:

- inspections and repairs - a locomotive is not in service,

- technical readiness - a locomotive is ready for operation,

- standby mode - a locomotive is ready for operation and remains in a railway depot, on a station or on a railway siding without a train driving crew and without any assigned tasks,

- operation - a locomotive with a crew performs an assigned task,

- light engine operation - a locomotive operating without railcars. It moves along the tracks to a predetermined location in order to collect the railcars, shunt or perform other tasks such as a supporting operation in conjunction with special railway vehicles. We also deal with this kind of operation if the locomotive runs to and from the locomotive repair

a) b)

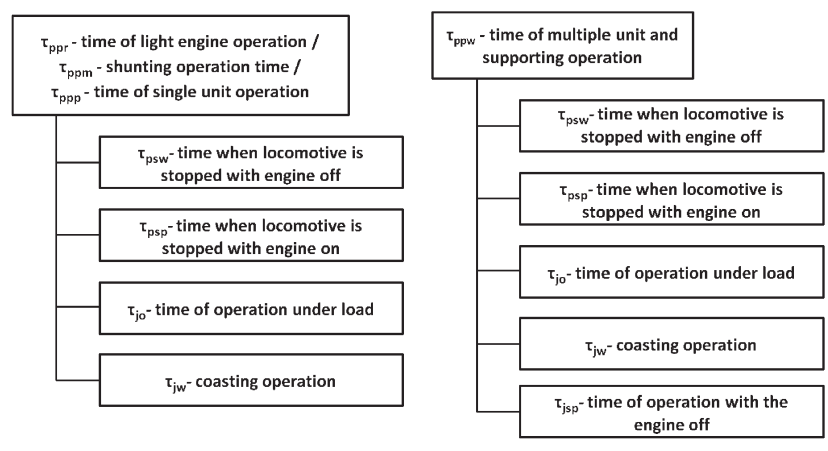

Fig. 6. Time structure of the operating states of diesel-electric locomotives: a) transport operation, shunting and single unit operation, b) multiple unit and supporting operation

Rys. 6. Struktura czasowa warunków eksploatacji lokomotyw spalinowych z przekładniami elektrycznymi: a) podczas pracy przesyłowej, pracy manewrowej, pracy pociagowej $w$ trakcji pojedynczej, b) podczas pracy pociagowej $w$ trakcji wielokrotnej lub pracy wspomagajacej układ energetyczny obejmuje elementy paliwochłonne, $\mathrm{tj}$. silniki cieplne (spalinowe), kocioł opalany (wytwornica ciepła) oraz urządzenia przekształcające rodzaje energii (prądnice, turbiny utylizacyjne), a także urządzenia zmieniające parametry strumieni energii (przekładnie, kotły utylizacyjne). Autonomiczne układy energetyczne w transporcie drogowym i kolejowym, jak również jednostki pływające w transporcie morskim, wykazują w tym względzie wiele analogii [2]. Do dalszej analizy proponuje się strukturę warunków eksploatacji lokomotyw spalinowych wzorowaną na rozwiązaniu przedstawionym na rys. 4. Propozycja ogólnej struktury czasowej warunków eksploatacji lokomotyw spalinowych z przekładniami elektrycznymi (rys. 5) bazuje na wieloletnim doświadczeniu eksploatacyjnym jednego $\mathrm{z}$ autorów i jednoczenie wykorzystuje terminologię branżową powszechnie wykorzystywaną w transporcie kolejowym.

Istotnym problemem podczas analizy warunków eksploatacji lokomotyw jest cykliczność zmian warunków zewnętrznych. Warunki te mogą mieć bezpośredni wpływ na eksploatację lokomotyw wynikającą np. z innego współczynnika tarcia między kołem a szyną w okresie jesiennym lub koniecznością wstępnego podgrzewania silników spalinowych. Zauważalny jest również wpływ pośredni warunków zewnętrznych, np. w postaci wzrostu masy przewożonego paliwa w okresie zimowym. W celu uwzględnienia wpływu takich czynników na pracę lokomotyw spalinowych należałoby przeprowadzać analizę czasową struktury warunków eksploatacji dla okresu 1 roku. W okresie tym lokomotywa jest poddawana planowym przeglądom i naprawom w czasie $\left(\tau_{\mathrm{n}}\right)$, jak również znajduje się w stanie gotowości technicznej w czasie $\left(\tau_{\mathrm{g}}\right)$. Zgodnie z zaproponowaną na rys. 5 strukturą można wymienić następujące warunki eksploatacji lokomotyw spalinowych z przekładniami elektrycznymi:

- przeglądy i naprawy - lokomotywa nie może być wykorzystywana do wykonywania pracy,

- gotowość techniczna - lokomotywa jest zdolna do wykonywania pracy,

- postój w rezerwie - lokomotywa jest przygotowana do pracy i przebywa na terenie lokomotywowni, stacji lub bocznicy bez załogi obsługującej oraz bez wyznaczonego zadania,

- praca lokomotywy - lokomotywa wraz z załogą wykonuje wyznaczone zadanie:

- praca przesylowa - lokomotywa poruszająca się po szlaku kolejowym bez wagonów w celu dojazdu do miejsca podjęcia wagonów, wykonywania prac manewrowych lub innych prac, takich jak prace pomocnicze czy prace ze specjalnymi pojazdami kolejowymi. Z pracą przesyłową mamy również do czynienia $\mathrm{w}$ ramach potrzeb własnych lokomotywowni, w sytuacji przejazdu lokomotywy do miejsca i z miejsca wykonywania napraw okresowych, skierowania lokomotywy do innej lokomotywowni oraz jazdy próbnej,

- praca manewrowa - lokomotywa wykorzystywana jest do rozrządu i zestawiania pociągów, 
shop for periodic repairs, is dispatched to another railway depot or is executing a test drive.

- shunting - distribution and assembling trains, delivering and collecting railcars at a cargo point, delivering and collecting railcars at platforms on a holding track, adjustment of railcars, groups of railcars and trains from one track to another, delivering trains and other railcars for cleaning, washing, decontamination, weighing, repairs, etc.

- single unit operation - a locomotive is used to pull or push vehicles on a railway track in accordance with a prescribed timetable.

- multiple unit and supporting operation - a train is hauled or pushed by at least two locomotives. This kind of operation is characteristic of trains whose designated route runs along electrified and nonelectrified tracks with different gradients or if the number of railcars is changed in a heavy cargo train. The difference between multiple unit operation and supporting operation is the way of the locomotive control. In the former the locomotives are connected by multiple couplings that enable a simultaneous control of the whole traction equipment from a single location in the lead locomotive. In the latter the additional locomotive has its own driving crew and is controlled from its own control panel.

In the framework of the above-listed operating conditions: running without cargo, shunting, single, multiple or supporting operation there is a possibility to list the operating conditions in detail that significantly differ from one another in terms of the combustion engine application, the generated power and, consequently, the weight of the consumed fuel in the period under consideration.

According to the proposed structure presented in Figure 6 , we may distinguish the following service conditions of a diesel locomotive for light engine operation, transport operation, shunting, single/multiple unit or support operation:

Locomotive stopped with combustion engine turned off - during shunting operations it is possible to shut off the engine during locomotive stops. However, this requires a precise organization of the shunting operations.

Locomotive stopped with combustion engine operating - during stops on a rail route the engine normally operates at idle. This is due to relatively short stop times. This state of operation may be the inability to continue driving before a semaphore. A locomotive stop can also be performed to unlock the railway route for a train of a higher priority.

Locomotive under load - when the engine power is transmitted via the electric gear to the wheelsets.

Coasting - the engine runs at idle while the locomotive is in motion. A considerable share of time of coasting is characteristic of rail transport and results from a relatively low rolling resistance and high kinetic energy stored in the moving masses of locomotives and railcars.

Riding with the engine off - can occur only in multiple unit or support operations. This is the case when there is podstawiania wagonów na punkty ładunkowe oraz ich zabierania, podstawiania i zabierania składów pasażerskich na perony i z peronów na grupę odstawczą, przestawiania wagonów, grup wagonów i całych składów pociągowych $\mathrm{z}$ jednego toru na drugi, podstawiania wagonów lub innych pojazdów kolejowych do wykonania czynności dodatkowych, jak: czyszczenie, mycie, odkażanie, ważenie, naprawy itp.,

- praca pociągowa $w$ trakcji pojedynczej - lokomotywa wykorzystywana jest do ciągnięcia lub pchania wagonów, albo innych pojazdów kolejowych na szlaku kolejowym zgodnie z wyznaczonym rozkładem jazdy,

- praca pociągowa w trakcji wielokrotnej lub praca wspomagająca - prowadzenie pociągu odbywa się za pomocą co najmniej dwóch lokomotyw. Ten rodzaj pracy charakterystyczny jest dla pociągów, których trasa wyznaczona jest szlakami o dużym zróżnicowaniu pochyleń, przebiega zarówno szlakami zelektryfikowanymi, jak i niezelektryfikowanymi, lub gdy na trasie pociągu następuje zmiana liczby wagonów w składzie o dużej masie. Różnica pomiędzy pracą w trakcji wielokrotnej a pracą wspomagającą polega na sposobie sterowania lokomotyw. W pierwszym przypadku lokomotywy połączone są za pomocą sprzęgów wielokrotnych, co umożliwia ich sterowanie z jednego stanowiska sterowniczego znajdującego się w lokomotywie prowadzącej. W przypadku pracy wspomagającej dodatkowa lokomotywa posiada własną drużyną trakcyjną, a sterowanie nią odbywa się z własnego stanowiska sterowniczego.

W ramach wymienionych warunków eksploatacji: pracy przesyłowej, pracy manewrowej, pracy pociągowej w trakcji pojedynczej i pracy pociągowej w trakcji wielokrotnej lub pracy wspomagającej wymienić można bardziej szczegółowo kolejne warunki eksploatacji (rys. 6), które w zasadniczy sposób różnią się ze względu na sposób wykorzystania silnika spalinowego, generowaną moc, a w konsekwencji również masę zużywanego paliwa w rozważanym okresie.

Zgodnie z zaproponowaną na rys. 6 strukturą można wymienić następujące warunki eksploatacji lokomotyw spalinowych z przekładniami elektrycznymi podczas pracy przesyłowej, manewrowej, pociągowej w trakcji pojedynczej i wielokrotnej lub wspomagającej:

Postój z wylączonym silnikiem spalinowym - podczas przeprowadzania prac manewrowych możliwa jest realizacja postoju z silnikiem wyłączonym. Wymaga to jednak dokładnej organizacji tych prac.

Postój z pracującym silnikiem spalinowym - podczas pracy na szlaku realizacja postoju odbywa się zazwyczaj przy włączonym silniku spalinowym pracującym na biegu jałowym. Wynika to ze stosunkowo krótkich okresów postoju. Ten stan realizowany jest w następstwie braku możliwości kontynuowania jazdy spowodowanej wskazaniem przez semafor sygnału „stój”. Postój jest również realizowany na dodatkowych torach stacyjnych, na które jest skierowany 
no demand for power from the additional locomotive and therefore its engine is turned off.

In the description of the operating conditions of locomotives appears the term engine idling, which, in the case of locomotives, differs from the general definition of the operating state of an engine under which the energy supplied to the engine is consumed exclusively to cover its friction losses. For locomotives the engine idling determines the state of the engine operation with no transfer of power to the wheelsets and auxiliary devices, such as the air compressor, generator (alternator) or auxiliary heating systems for passenger trains.

In order to obtain quantitative characteristics of the elements of the structure of the operating conditions useful for comparative analyses and calculations, the shares of time for different modes of operation in the considered operation period should be used:

$$
\lambda_{y}^{\mathrm{x}}=\frac{\tau_{\mathrm{x}}}{\tau_{\mathrm{y}}}
$$

where: $\tau_{\mathrm{x}}$ - time of diesel-electric locomotive operation in $\mathrm{x}$ mode, $\tau_{\mathrm{y}}$ - operation period selected for the analysis, e.g. 1 year.

Assuming, for example, that the total time of a given locomotive operation selected for analysis is $\tau_{p}$, the time of operation in a transport mode $-\tau_{\text {ppr }}$, in shunting $-\tau_{p p m}$, in a single unit operation $\tau_{\mathrm{ppp}}$, in a multiple unit or supporting operation $-\tau_{p p w}$, one can determine the shares of time of operation in a light engine operation mode $-\lambda_{\mathrm{p}}^{\mathrm{ppr}}$, in shunting $-\lambda_{\mathrm{p}}^{\mathrm{ppm}}$, in a single unit configuration $\lambda_{\mathrm{p}}^{\mathrm{ppp}}$ and in a multiple unit or supporting operation.

In addition, driving under load can be quantitatively characterized by a histogram of distribution of average values of the time of operation under load in the assumed ranges of relative power.

\section{Examples of analyses of time structures of operating states of diesel-electric locomotives}

An essential problem in the analysis of operating time of a locomotive and its propulsion system is the identification of sources of information [5]. One of the documents containing extensive information is the Train Driver Crew and Vehicle Operation Sheet. This document contains the driver data, time and place of the beginning and end of the locomotive operation, type of work, identification number of the train, time of operation and stops, distance travelled, total number of axles, gross train weight and amount of fuel in the tank at the beginning and at the end of the locomotive operation. The sheet also includes information about delays and faults.

A useful source of information on the operating conditions are the monitoring devices of the fuel flow rate consumed by the engine increasingly often fitted in diesel locomotives. The type of data provided by these systems depends on their complexity. The simplest systems make comparisons of demand for power by the traction motors with the amount pociąg towarowy lub lokomotywa w celu odblokowania szlaku dla pociągu o wyższej kategorii.

Jazda pod obciążeniem, podczas której moc z silnika spalinowego przekazywana jest za pośrednictwem przekładni elektrycznej na zestawy kołowe.

Jazda wybiegiem, podczas której silnik pracuje na biegu jałowym. Znaczny udział czasu jazdy wybiegiem jest charakterystyczny dla transportu kolejowego i wynika z relatywnie małych oporów ruchu i dużej energii kinetycznej zgromadzonej w poruszającej się masie lokomotywy oraz wagonów.

Jazda z wyłączonym silnikiem spalinowym, która może występować wyłącznie w przypadku pracy pociągowej w trakcji wielokrotnej lub pracy wspomagającej. Występuje to wtedy, gdy nie ma zapotrzebowania na moc dodatkowej lokomotywy, a jej silnik spalinowy jest wyłączony.

W opisie warunków eksploatacji lokomotywy pojawiło się także pojęcie biegu jałowego silnika spalinowego, które dla lokomotyw różni się od ogólnej definicji stanu pracy silnika, w którym energia doprowadzona do silnika zużywana jest na pokrycie własnych oporów ruchu. W odniesieniu do silników pojazdów kolejowych stanem biegu jałowego określa się zwyczajowo stan pracy silnika przy braku przekazywania mocy na zestawy kołowe oraz do napędu wielu urządzeń pomocniczych pojazdu, takich jak: sprężarka powietrza, prądnica pomocnicza lub prądnica ogrzewcza odnośnie do lokomotyw pasażerskich.

W celu uzyskania charakterystyk elementów struktury warunków eksploatacji, przydatnych do przeprowadzenia analiz porównawczych oraz obliczeń, należy posługiwać się udziałami czasu poszczególnych rodzajów pracy w rozważanym okresie eksploatacji - wzór (1), gdzie: $\tau_{\mathrm{x}}$ - czas eksploatacji lokomotywy spalinowej z przekładnią elektryczną w rozważanym okresie eksploatacji, $\tau_{\mathrm{y}}$ - rozważany okres eksploatacji, np. 1 rok.

Przyjmując przykładowo, że rozważany okres pracy danej lokomotywy wynosi $\tau_{p}$, czas pracy przesyłowej $\tau_{\text {ppr' }}$, manewrowej $\tau_{\text {ppm }}$, pociągowej $\mathrm{w}$ trakcji pojedynczej $\tau_{\text {ppp }}$, pociągowej w trakcji wielokrotnej lub wspomagającej $\tau_{\text {ppw' }}$, można wyznaczyć udziały czasu pracy: przesyłowej manewrowej $\lambda_{\mathrm{p}}^{\mathrm{ppm}}$, pociągowej $\mathrm{w}$ trakcji pojedynczej $\lambda_{\mathrm{p}}^{\mathrm{ppp}}$ i pociągowej w trakcji wielokrotnej lub wspomagającej $\lambda_{\mathrm{p}}^{\mathrm{ppw}}$.

Ponadto jazdę pod obciążeniem można scharakteryzować za pomocą histogramu udziału czasu jazdy pod obciążeniem dla przyjętych przedziałów względnej mocy napędu.

\section{Przykłady analizy struktur czasowych warunków eksploatacji lokomotyw spalinowych}

Istotnym problemem $\mathrm{w}$ procesie analizy czasów pracy lokomotywy oraz jej układu napędowego jest określenie źródeł informacji [5]. Jednym z dokumentów, który zawiera szeroki zakres informacji jest Karta Pracy Drużyny Trakcyjnej i Pojazdów. Dokument ten obejmuje dane maszynisty, czas i miejsce rozpoczęcia i zakończenia pracy lokomotywy, rodzaj pracy lokomotywy, numer pociągu, czas jazdy, czas postoju, przebytą drogę, sumaryczną liczbę osi całego 
of consumed fuel. The internal memory of the monitoring devices saves information about the changes in volume of the fuel in the tank and the electricity consumed at specified time intervals as well as on activating and deactivating the engine or locomotive drive off and braking. The data from this system are periodically scanned by the Rolling Stock Department and submitted for analysis. Schematics of this system have been shown in Figure 7. The system is equipped with a GPS and allows recording many parameters such as: locomotive speed, fuel level in the tank, voltage, the current in the electric transmission and engine speed.

Examples of the results of measurements with the system installed in the SM 31, SM 42 and ST44 locomotives by PKP CARGO SA are shown in Table 1.

It should be clarified that in the case of the Polish Railway Group (PKP) there is an alphanumeric system of names used that accurately characterizes the tractor units. The first letter in the name determines the type of propulsion and the letter "S" denotes a diesel locomotive. The second letter indicates the intended use of the vehicle, where ' $M$ '

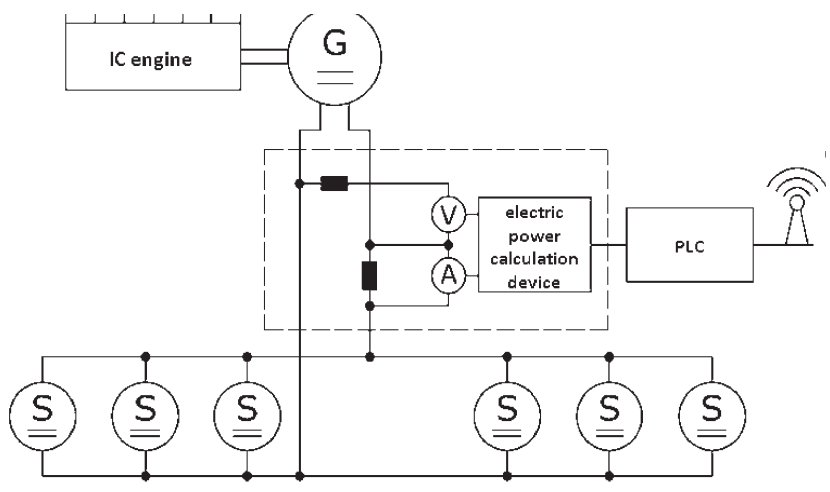

Fig. 7. Schematics of the mesuring sytem of a diesel-electric locomotive Rys. 7. Schemat systemu pomiarowego lokomotywy z przekładnia elektryczna

stands for shunting and ' $\mathrm{T}$ ' traction work. The numbers after the letter inform about the exact design characteristics of the tractor unit, such as the number of axles, type of gear in diesel locomotives and the ability to operate in multiple unit configuration.

It follows from the above data that the share of time of the shunting of SM 31 and SM 42 locomotives is 0.843 and 0.881 respectively and the share of time of operation in single and multiple configurations of ST44 locomotives totals at składu, masę pociągu brutto oraz ilość paliwa na początku i na końcu pracy. W Karcie Pracy Drużyny Trakcyjnej i Pojazdów zawarte są również informacje o opóźnieniach, a także uwagi dotyczące usterek.

Przydatnym źródłem informacji o warunkach eksploatacji są systemy monitoringu objętościowego strumienia paliwa zużywanego przez silnik, które coraz częściej montowane są w lokomotywach spalinowych. Rodzaj danych dostarczanych przez te systemy zależy od stopnia ich rozbudowania. Najprostsze systemy dokonują porównania zapotrzebowania energii elektrycznej przez silniki trakcyjne z ubytkiem objętości paliwa ze zbiorników. W pamięci wewnętrznej urządzenia monitorującego są zapisywane informację o zmianie objętości paliwa w zbiorniku i zużytej energii elektrycznej w określonych przedziałach czasu oraz o włączaniu i wyłączaniu silnika spalinowego, rozpoczęciu jazdy lub hamowania lokomotywy. Dane z tego systemu są okresowo odczytywane na terenie zakładu taboru i przekazywane do analizy. Schemat takiego systemu przedstawiono na rys. 7. System jest wyposażony w układ lokalizacji GPS oraz umożliwia rejestrowanie wielu parametrów, np.: prędkości lokomotywy, poziomu paliwa w zbiorniku, napięcia i natężenia prądu w przekładni elektrycznej, prędkości obrotowej silnika spalinowego.

W tabeli 1 podano przykładowe wyniki pomiarów czasu pracy zarejestrowanych za pomocą systemu zainstalowanego w lokomotywach serii SM 31, SM 42 i ST44 eksploatowanych przez PKP CARGO S.A.

Należy wyjaśnić, że w odniesieniu do firmy grupy PKP stosuje się system nazw literowo-cyfrowych dokładnie charakteryzujący pojazdy kolejowe. Pierwsza litera w nazwie określa rodzaj trakcji i litera „S” oznacza trakcję spalinową. Druga litera oznacza przeznaczenie pojazdu kolejowego, gdzie „M” oznacza lokomotywę manewrową, a „T”- lokomotywę pociągową towarową. Cyfry za oznaczeniem literowym informują o dokładnych cechach konstrukcyjnych pojazdów szynowych, takich jak liczba osi, rodzaj przekładni w przypadku pojazdów spalinowych oraz możliwości pracy w trakcji wielokrotnej.

Z powyższych danych wynika, że udziały czasu pracy manewrowej dla lokomotyw SM 31 i SM 42 wynoszą odpowiednio 0,843 i 0,881 , a udział czasu pracy pociągowej zarówno w trakcji pojedynczej, jak i wielokrotnej dla lokomotywy ST44 wynosi łącznie 0,625. Świadczy to o wykorzystaniu lokomotyw danych serii zgodnie z ich przeznaczeniem.

Table 1. Times and shares of time of the locomotive operating states in light engine, shunting and transport operation (data courtesy of PKP CARGO S.A.) Tabela 1. Czasy i udziały czasu pracy przesyłowej, manewrowej i pociagowej dla trzech lokomotyw (dane uzyskane dzięki uprzejmości PKP CARGO S.A.)

\begin{tabular}{|c|c|c|c|c|c|c|c|c|c|c|}
\hline \multirow[t]{2}{*}{$\begin{array}{c}\text { Type of } \\
\text { locomotive/ } \\
\text { seria loko- } \\
\text { motywy }\end{array}$} & \multirow[t]{2}{*}{$\begin{array}{l}\text { Number of } \\
\text { locomo- } \\
\text { tives/liczba } \\
\text { lokomotyw }\end{array}$} & \multirow{2}{*}{$\begin{array}{c}\text { Total op- } \\
\text { eration time/ } \\
\text { sumaryczny } \\
\text { czas pracy } \\
\tau_{\mathrm{p}}[\mathrm{h}]\end{array}$} & \multicolumn{2}{|c|}{$\begin{array}{l}\text { Light engine } \\
\text { operation/praca } \\
\text { przesylowa }\end{array}$} & \multicolumn{2}{|c|}{$\begin{array}{c}\text { Shunting/praca } \\
\text { manewrowa }\end{array}$} & \multicolumn{2}{|c|}{$\begin{array}{l}\text { Single unit operation/ } \\
\text { praca pociagowa } \\
\text { w trakcji pojedynczej }\end{array}$} & \multicolumn{2}{|c|}{$\begin{array}{l}\text { Multiple unit and } \\
\text { supporting operation } \\
\text { praca pociagowa } \\
\text { w trakcji wielokrotne }\end{array}$} \\
\hline & & & $\tau_{\mathrm{ppr}}[\mathrm{h}]$ & $\lambda_{\mathrm{p}}^{\text {ppr }}[-]$ & $\tau_{\mathrm{ppm}}[\mathrm{h}]$ & $\lambda_{\mathrm{p}}^{\mathrm{ppm}}[-]$ & $\tau_{\mathrm{ppp}}[\mathrm{h}]$ & $\lambda_{p}^{p p p}[-]$ & $\tau_{\mathrm{ppw}}[\mathrm{h}]$ & $\lambda_{\mathrm{p}}^{\mathrm{ppw}}[-]$ \\
\hline SM 31 & 28 & 31829 & 2247 & 0.071 & 26828 & 0.843 & 1627 & 0.051 & 1125 & 0.035 \\
\hline SM42 & 72 & 105784 & 3701 & 0.035 & 93246 & 0.881 & 8731 & 0.083 & 105 & 0.001 \\
\hline ST44 & 9 & 4118 & 777 & 0.189 & 765 & 0.186 & 1805 & 0.438 & 770 & 0.187 \\
\hline
\end{tabular}


0.625 . This demonstrates that the given series of locomotives are used in accordance with their intended use.

The results of the measurements including the times and the time shares of each operating mode of the SM42 locomotive are presented in Table 2. During the operation under load
W tabeli 2 podano wyniki pomiarów zawierające czasy i udziały czasu poszczególnych rodzajów eksploatacji lokomotyw serii SM42, przy czym przy jeździe pod obciążeniem wyszczególniono jeszcze pięć zakresów pracy odpowiadających kolejnym zakresom względnej mocy elektrycznej

Table 2. The shares of stoppage, coasting and operation under load of three locomotives during shunting operation (data courtesy of PKP CARGO S.A.) Tabela 2. Udziały czasu postojów i pracy pod obciązeniem dla trzech lokomotyw serii SM42 podczas pracy manewrowej (ppm) (dane uzyskane z PKP CARGO S.A.)

\begin{tabular}{|c|c|c|c|c|c|c|c|c|}
\hline \multirow[t]{2}{*}{ Lp. } & \multirow{2}{*}{$\begin{array}{c}\text { Time share of stoppage } \\
\text { with engine turned off/ } \\
\text { udziat postoju z silnikiem } \\
\text { wytaczonym } \lambda_{\mathrm{ppm}}^{\mathrm{psw}}[-]\end{array}$} & \multirow{2}{*}{$\begin{array}{c}\text { Time share of stops } \\
\text { with engine operating/ } \\
\text { udziat postoju } z \text { silnikiem } \\
\text { wtaczonym } \lambda_{\mathrm{ppm}}^{\mathrm{psp}}[-]\end{array}$} & \multirow{2}{*}{$\begin{array}{c}\text { The times share } \\
\text { of coasting/udziat } \\
\text { jazdy na wybiegu } \\
\lambda_{\mathrm{ppm}}^{\mathrm{jw}}[-]\end{array}$} & \multicolumn{5}{|c|}{$\begin{array}{l}\text { Time share of operation under load/udziat jazdy } \\
\qquad \text { pod obciążeniem } \lambda_{\mathrm{ppm}}^{\text {jo }}[-]\end{array}$} \\
\hline & & & & $\begin{array}{c}\overline{\mathrm{N}}_{\mathrm{el}} \in \\
<0 ; 0.2>\end{array}$ & $\begin{array}{c}\bar{N}_{\mathrm{el}} \in \\
(0.2 ; 0.4>\end{array}$ & $\begin{array}{c}\bar{N}_{\mathrm{el}} \in \\
(0.4 ; 0.6>\end{array}$ & $\begin{array}{c}\bar{N}_{\mathrm{el}} \in \\
(0.6 ; 0.8>\end{array}$ & $\begin{array}{c}\overline{\mathrm{N}}_{\mathrm{el}} \in \\
(0.8 ; 1>\end{array}$ \\
\hline 1 & 0.327 & 0.417 & 0.048 & 0.168 & 0.020 & 0.010 & 0.006 & 0.004 \\
\hline 2 & 0.169 & 0.583 & 0.041 & 0.164 & 0.024 & 0.010 & 0.005 & 0.004 \\
\hline 3 & 0.415 & 0.403 & 0.066 & 0.082 & 0.016 & 0.011 & 0.005 & 0.002 \\
\hline
\end{tabular}

five more operating states were distinguished corresponding to the individual ranges of relative power $\left(\overline{\mathrm{N}}_{\mathrm{el}}\right)$ generated by the generator of the diesel-electric locomotive during shunting operation (ppm).

In the applied description, the time of shunting operation was adopted as an operation period under consideration. In individual cases, transport operation time or traction work time can also be adopted as the operation period under analysis.

Based on the results shown in Table 2 it can be concluded that in shunting operation the SM42 locomotives most of the time are in the standby mode at idle or with the engine turned off but when running under load the engine operation mainly generates minimum electrical power $\overline{\mathrm{N}}_{\mathrm{el}} \leq 0.2$.

The results of the measurements including the shares of time of the individual modes of operation of the ST44 locomotives in single unit operation (ppp) are presented in Table 3. It follows from the table that in the case of ST44 locomotives operated in single unit configuration, the share of time in the standby mode with the engine at idle as well as turned off is decreasing substantially in favour of driving under load. Also, the share of time in coasting increases significantly due to higher speeds of the train. In addition, similarly to locomotives performing the shunting operation (Table 2) also in this case when running under load the engine generates minimum electricity $\overline{\mathrm{N}}_{\mathrm{el}} \leq 0.2$ and the share of time under full load is negligible.
$\left(\overline{\mathrm{N}}_{\mathrm{el}}\right)$ generowanej w prądnicy przekładni elektrycznej podczas pracy manewrowej (ppm). W zastosowanym opisie przyjęto czas pracy manewrowej jako rozważany okres eksploatacji. W poszczególnych przypadkach jako rozważany okres eksploatacji może byc przyjęty również czas pracy pracy przesyłowej, pociągowej itd.

Na podstawie analizy danych przedstawionych w tabeli 2 można stwierdzić, że lokomotywy serii SM42 podczas pracy manewrowej większość czasu są w postoju (zarówno z silnikiem włączonym, jak i wyłączonym), natomiast podczas jazdy pod obciążeniem dominuje praca silnika przy generowaniu minimalnej mocy elektrycznej $\overline{\mathrm{N}}_{\mathrm{el}} \leq 0,2$.

$\mathrm{W}$ tabeli 3 podano wyniki pomiarów zawierające udziały czasu poszczególnych rodzajów eksploatacji lokomotyw serii ST44 podczas pracy pociągowej w trakcji pojedynczej (ppp).

$\mathrm{Na}$ podstawie analizy wyników z tabeli 3 można stwierdzić, że dla lokomotyw serii ST44, podczas pracy pociągowej w trakcji pojedynczej, znacząco zmniejsza się udział czasu postoju (zarówno z silnikiem włączonym, jak i wyłączonym) na korzyść jazdy pod obciążeniem. Wyraźnie rośnie również udział czasu jazdy wybiegiem ze względu na wyższe prędkości osiągane przez skład. Ponadto, podobnie jak w przypadku lokomotyw wykonujących pracę manewrową (tab. 2), również w tym przypadku podczas jazdy pod obciążeniem dominuje praca silnika przy generowaniu minimalnej mocy elektrycznej $\overline{\mathrm{N}}_{\mathrm{el}} \leq 0,2$, a udział czasu pracy

Table 3. The shares of stoppage, coasting and operation under load of three locomotives during single unit operation (data courtesy of PKP CARGO S.A.)

Tabela 3. Udziały czasu postojów i pracy pod obciażeniem dla trzech lokomotyw serii ST44 podczas pracy pociagowej w trakcji pojedynczej (ppp) (dane uzyskane z PKP CARGO S.A.)

\begin{tabular}{|c|c|c|c|c|c|c|c|c|}
\hline \multirow[t]{2}{*}{ Lp. } & \multirow{2}{*}{$\begin{array}{l}\text { Time share of stoppage } \\
\text { with engine turned off/ } \\
\text { udziat postoju z silnikiem } \\
\text { wytaczonym } \lambda_{\mathrm{ppm}}^{\mathrm{psw}}[-]\end{array}$} & \multirow{2}{*}{$\begin{array}{c}\text { Time share of stops } \\
\text { with engine operating/ } \\
\text { udziat postoju z silnikiem } \\
\text { wtaczonym } \lambda_{\mathrm{ppm}}^{\mathrm{psp}}\end{array}$} & \multirow{2}{*}{$\begin{array}{c}\text { The times share } \\
\text { of coasting/udziat } \\
\text { jazdy na wybiegu } \\
\lambda_{\mathrm{ppm}}^{\mathrm{jw}}[-]\end{array}$} & \multicolumn{5}{|c|}{$\begin{array}{l}\text { Time share of operation under load/udziat jazdy } \\
\text { pod obciążeniem } \lambda_{\mathrm{ppm}}^{\mathrm{jo}}[-]\end{array}$} \\
\hline & & & & $\begin{array}{c}\overline{\mathrm{N}}_{\mathrm{el}} \in \\
<0 ; 0.2>\end{array}$ & $\begin{array}{c}\overline{\mathrm{N}}_{\mathrm{el} \in} \\
(0.2 ; 0.4>\end{array}$ & $\begin{array}{c}\overline{\mathrm{N}}_{\mathrm{el}} \in \\
(0.4 ; 0.6>\end{array}$ & $\begin{array}{c}\bar{N}_{e l} \in \\
(0.6 ; 0.8>\end{array}$ & $\begin{array}{c}\overline{\mathrm{N}}_{\mathrm{el}} \in \\
(0.8 ; 1>\end{array}$ \\
\hline 1 & 0.064 & 0.200 & 0.272 & 0.246 & 0.115 & 0.044 & 0.046 & 0,013 \\
\hline 2 & 0.029 & 0.240 & 0.284 & 0.249 & 0.106 & 0.054 & 0.034 & 0.004 \\
\hline 3 & 0.068 & 0.411 & 0.182 & 0.139 & 0.075 & 0.036 & 0.074 & 0.015 \\
\hline
\end{tabular}


Table 4. The results of measurements including stoppage, coasting, operation under load and the weight of fuel

Tabela 4. Wyniki pomiarów zawierające czas postojów, jazdy wybiegiem i pod obciązeniem oraz masę paliwa zużytego przez lokomotywę serii ST44 podczas pracy pociagowej w trakcji pojedynczej (ppp) (dane uzyskane z PKP CARGO S.A.)

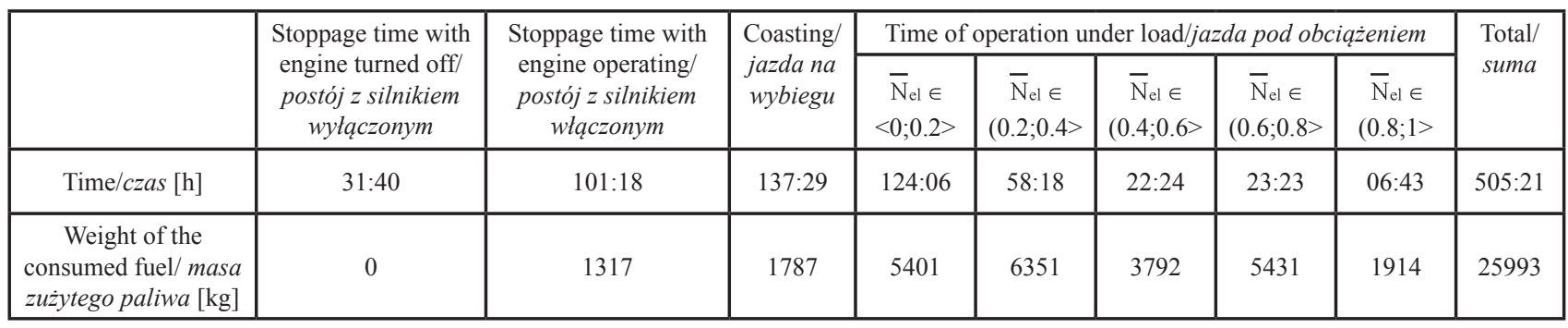

Table 4 contains the results of measurements including the time and weight of fuel consumed by the ST44 locomotive operated in various modes in single unit configuration (ppp).

From the results shown in Table 4 it can be concluded that during operation in single unit configuration, in the case of the locomotive under consideration, the largest weight of fuel was consumed during operation under load in the relative power range $0.2<\mathrm{N}_{\mathrm{el}} \leq 0.4$. One may also notice that the distribution of the weight of fuel used is relatively uniform in the full range of loads. The weight of fuel consumed by the engine at idling (standby mode and coasting) is about $20 \%$ of the total amount of the fuel consumed in the analysed transport operation.

\section{Conclusions}

The time structure of the operating conditions of dieselelectric locomotives proposed in the paper represents a significant simplification in relation to the structures currently used by operators and follows from operational experience in the analysis of their operation [16]. The level of detail of the proposed structure is flexible and allows adaptation to specific actual cases of operation. The values of the parameters found in the structure are a quantitative description of the service conditions of diesel-electric locomotives that can be used to predict fuel consumption, standardise and assess the energy efficiency of the locomotive powertrain. The knowledge of the predicted fuel consumption allows the cost of a given task to be accurately estimated, which may be important in the preparations of public tenders.

The proposed time structure of service conditions of diesel-electric locomotives may be used to assess the quality of maintenance as well as the efficiency of their usage. In the case of low efficiency of the vehicle use it may be decided to change the location of the locomotive and operate it in an area where it will be used more efficiently. Because of the division of the locomotive operation into, for example, train drive and shunting, it is possible to assess the compatibility of the locomotive usage with its design specifications.

The assessment of appropriateness of the locomotive selection for required tasks can be done after checking whether the selected locomotive has the appropriate maximum power. It is obvious that one cannot use locomotives of insufficient maximum power because it will fail to perform the required task. On the other hand, the use of a locomotive with an engine of excessive power output causes increased operating costs. układu napędowego przy pełnym obciążeniu jest znikomy.

W tabeli 4 podano wyniki pomiarów zawierające czas pracy i masę paliwa zużytego przez lokomotywę serii ST44 w poszczególnych warunkach eksploatacji podczas pracy pociągowej w trakcji pojedynczej (ppp).

$\mathrm{Na}$ podstawie analizy wyników podanych w tabeli 4 można stwierdzić, że podczas pracy pociągowej w trakcji pojedynczej, w przypadku rozważanej lokomotywy, największa masa paliwa została zużyta podczas jazdy pod obciążeniem w zakresie $0,2<\mathrm{N}_{\text {el max }} \leq 0,4$, można również zauważyć, że rozkład masy zużytego paliwa jest stosunkowo równomierny $\mathrm{w}$ pełnym zakresie obciążeń. Masa paliwa zużytego podczas pracy silnika na biegu jałowym (postój z silnikiem włączonym i jazda na wybiegu) stanowi ok. $20 \%$ całkowitej masy paliwa zużytego w okresie analizowanej pracy pociągowej.

\section{Podsumowanie}

Zaproponowana w pracy struktura czasowa warunków eksploatacji lokomotyw spalinowych z przekładniami elektrycznymi stanowi znaczne uproszczenie w stosunku do wykorzystywanych aktualnie przez krajowych przewoźników i wynika z doświadczeń eksploatacyjnych przy analizie pracy lokomotyw [16]. Poziom szczegółowości zaproponowanej struktury jest elastyczny i umożliwia jej dostosowanie do szczególnych przypadków eksploatacji. Wartości parametrów występujących w tej strukturze stanowią ilościowy opis warunków eksploatacji lokomotyw spalinowych z przekładniami elektrycznymi, który może być wykorzystany do prognozowania i normowania zużycia paliwa oraz oceny efektywności energetycznej układu napędowego lokomotywy. Znajomość prognozowanego zużycia paliwa pozawala na dokładne określenie kosztów wykonania danego zadania, co może być istotne przy np. tworzeniu oferty przetargowej.

Zaproponowana w pracy struktura czasowa warunków eksploatacji lokomotyw może być użyta do oceny jakości utrzymania oraz do oceny efektywności ich wykorzystania. Przy stwierdzeniu niskiej efektywności możliwe jest podjęcie decyzji o zmianie lokalizacji lokomotywy i eksploatowanie jej na obszarze, gdzie będzie efektywniej wykorzystywana. Dzięki wprowadzeniu do struktury podziału na rodzaje pracy, np. manewrową i pociągową, możliwa jest ocena zgodności wykorzystania lokomotywy z jej konstrukcyjnym przeznaczeniem. 
The information obtained on the basis of the analysis of the use of the powertrain system may be useful in planning purchases of new locomotives. More attention is paid to such investments in order to meet the requirements of interoperability of rolling stock for railway freight [4].

In addition, the lease of locomotives becomes an increasingly common practice, which gives the opportunity to choose the most suitable ones from among many types having different maximum power outputs.

Following an optimal selection of the locomotives for designated tasks, it is possible not only to reduce the operating costs but also the costs of the above-mentioned lease.
Ocenę poprawności doboru lokomotywy do zadań można również dokonać po sprawdzeniu, czy do wykonywania określonej pracy została użyta lokomotywa o odpowiedniej mocy maksymalnej. Oczywiste jest, że nie można użyć lokomotywy o zbyt małej mocy maksymalnej, ponieważ nie będzie w stanie wykonać zadania. Natomiast użycie lokomotywy dysponującej zbyt dużą mocą maksymalną wiąże się ze zwiększonymi kosztami eksploatacyjnymi. Informacje uzyskane na podstawie analizy wykorzystania układu napędowego mogą być przydatne w planowaniu zakupu nowych lokomotyw. Coraz większą uwagę przy takich inwestycjach zwraca się również na spełnienie wymagania interoperacyjności taboru przeznaczonego do kolejowych przewozów towarowych [4]. Ponadto coraz powszechniejszą praktyką jest wynajmowanie lokomotyw, co daje możliwość wyboru najodpowiedniejszych spośród wielu typów pojazdów o różnych mocach maksymalnych. Dzięki właściwemu doborowi lokomotywy do wyznaczonego zadania możliwe jest ograniczenie nie tylko kosztów eksploatacji, ale również kosztów wspomnianego najmu.

\section{Bibliography/Literatura}

[1] Bai Y., Mao B., Zhou F., Ding Y., Dong Ch.: Energy-Efficient Driving Strategy for Freight Trains Based on Power Consumption Analysis. J Transpn Sys Eng \& IT, 2009, 9(3), 43-50.

[2] Balcerski A., Kneba Z., Kropiwnicki J., Makowski S.: The conception of exploitation efficiency of autonomic energy systems of land vehicles and ships. Combustion Engines R. 48, nr SC2, Mixture Formation, Ignition and Combustion, 2009, s. 70-76.

[3] Balcerski A.: Modele probabilistyczne w teorii projektowania i eksploatacji spalinowych siłowni okrętowych. Fundacja Promocji Przemysłu Okrętowego i Gospodarki Morskiej, Gdańsk 2007.

[4] Bartosik B.: Rozwój kolejowych przewozów towarowych w kontekście europejskiej polityki transportowej. Problemy Kolejnictwa, z. nr 144/2007, s. 41-50.

[5] Boguś P., Grzeszczyk R.: Wykrywanie i detekcja stanu pojazdu szynowego z użyciem GPS oraz innych pokładowych urządzeń rejestrujących. Pojazdy Szynowe nr 2/2010, s. 13-23.

[6] Ding Y., Zhou F., Bai Y., Li R., Mao B.: Train Grade Resistance Calculation Modification Model Based on Measured Data. J Transpn Sys Eng \& IT, 2010, 10(6), 82-88.

[7] Gronowicz J.: Energochłonność transportu kolejowego. Trakcja spalinowa. Wydawnictwo Komunikacji i Łączności, Warszawa 1990.

[8] Gronowicz J.: Studium nad estymatami energetycznymi lokomotywy spalinowej z przekładnią elektryczną. WPP, seria Rozprawy, nr 140, Poznań 1982.

Mr Paweł Kortas, MSc. - specialist engineer at Section of repair of rolling stock at PKP Intercity S.A.

Mgr inż. Pawel Kortas - specjalista mechanik w Sekcji Napraw Taboru PKP Intercity S.A. e-mail:pawel.kortas@gmail.com
[9] Hoffrichter A., Miller A.R., Hillmansen S., Roberts C.: Wellto-wheel analysis for electric, diesel and hydrogen traction for railways. Transportation Research Part D 17 (2012), 28-34.

[10] Kałuża E.: Analiza efektywności stosowania lokomotyw hybrydowych w pracy manewrowej. Zeszyty Naukowe Politechniki Śląskiej, s. Transport, z. 27, 1995, s. 157-165.

[11] Liu R.R., Golovitcher I.M.: Energy-efficient operation of rail vehicles. Transportation Research Part A 37 (2003), 917932.

[12] Marciniak J.: Eksploatacja kolejowych pojazdów szynowych. WKiŁ, Warszawa 1990.

[13] Marin G.D., Naterer G.F., Gabriel K.: Rail transportation by hydrogen vs. electrification a Case study for Ontario Canada, I: Propulsion and storage. International Journal of Hydrogen Energy 35 (2010), 6084-6096.

[14] Niziński S.: Eksploatacja obiektów technicznych. Wydaw. i Zakład Poligrafii Instytutu Technologii i Eksploatacji, Radom 2002.

[15] Park D., Yoon Y., Kwon S-B., Jeong W., Cho Y., Lee K.: The effects of operating conditions on particulate matter exhaust from diesel locomotive engines. Science of the Total Environment 419 (2012), 76-80.

[16] PKP CARGO S.A.: Instrukcja o gospodarce pojazdami i drużynami trakcyjnymi Ct-9, 2008.

[17] Yaghinia M., Sharifiana Sh., Akhavana R.: Reengineering the Locomotive Operation Management Process in the Railways of Iran (RAI). Procedia - Social and Behavioral Sciences 43 (2012), 86-97.

Kropiwnicki Jacek, DSc., DEng. - doctor in the Faculty of Mechanical Engineering at Gdańsk University of Technology.

Dr hab. inż. Jacek Kropiwnicki - adiunkt na Wydziale Mechanicznym Politechniki Gdańskiej.

e-mail: jkropiwn@pg.gda.pl

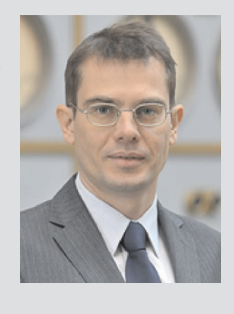

